د · جابر خليفة سالم العازمي

\title{
الفروق الفقهية
}

من باب الصلح من كتاب إيضاح الدلائل في الفرق

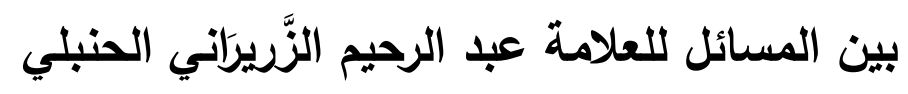
دراسة مقارنة

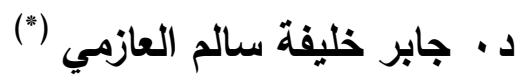

المقدمة :

إن الحمد لله نحمده ونستعينه ونستغفره ونعوذ باله من شرور أنفسنا ومن

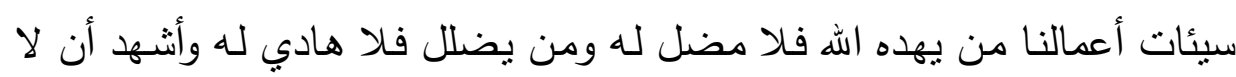
إله إلا الله وحده لا شريك له وأثهـ أن محمدا عبده ورسوله.

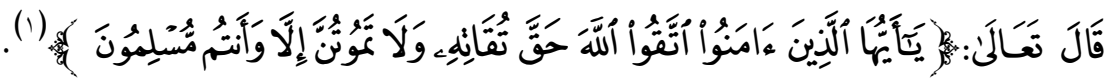

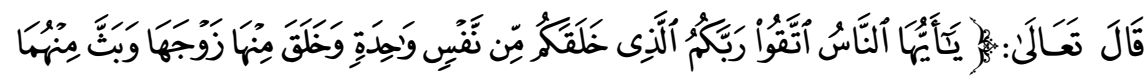

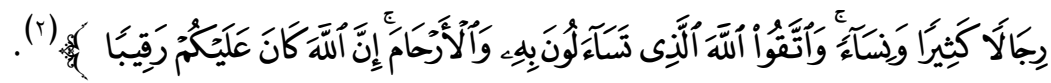

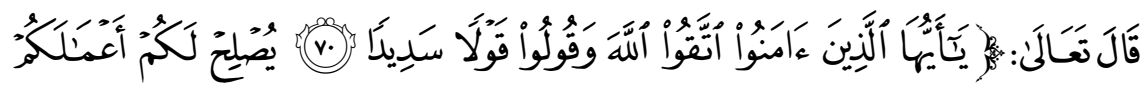

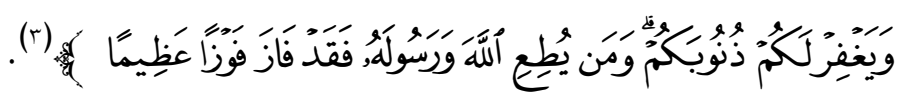
أما بعد:

فإن الفقه من أثشرف العلوم قدرا، وأسماها فخرا، وأعظمها أجرا، وأعمها فائدة، والحديث عن الفقه، ومكانته، ورفعة أهله في الدنيا والآخرة، لَيستفرغُ جهداً

$$
\begin{aligned}
& \text { باحث أول قانوني في وزارة الأوقاف والثنؤون الإنلامية /الكويت. }
\end{aligned}
$$

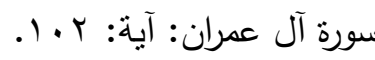

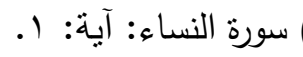

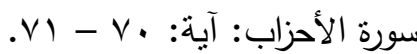




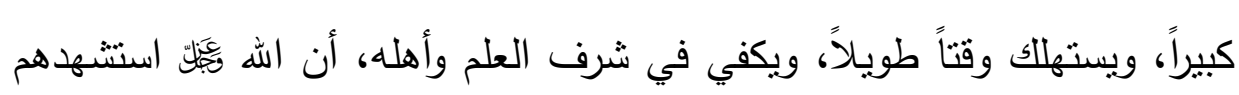
على وحدانيته، وأخبر أنهم هم الذين يخشونه على الحقيقة والكمال، قَالَ نَعَلَّ:

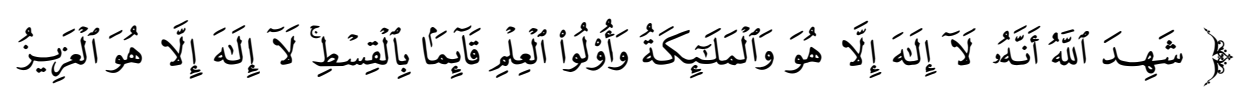

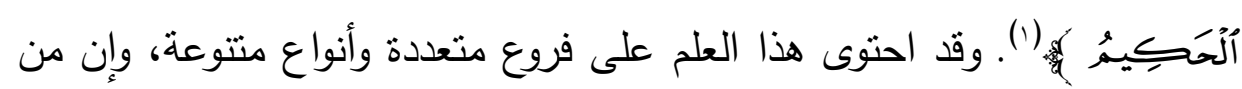

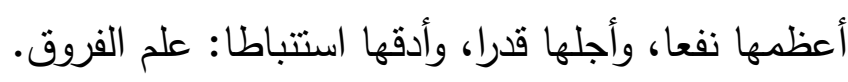

فلمّا عرف الفقهاء فضل العلم، ومكانته، سلكوا طريقه، فعكفا عليه، وصنفوا

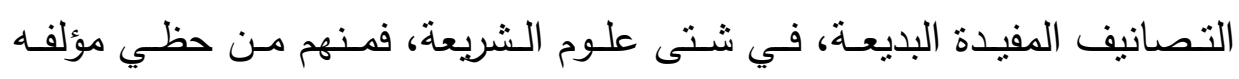

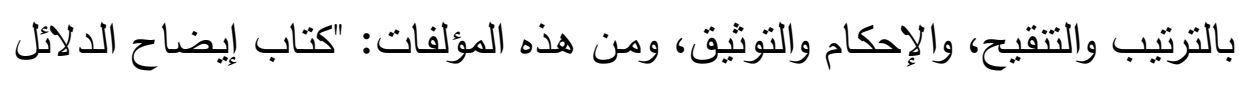

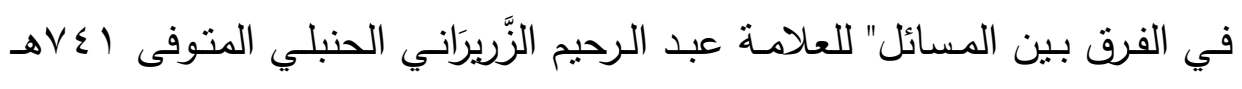
رحمه الله. فقد بحثت في هذا الكتاب مسائل الصلح دراسة فقهية مقارنة. والسبب في البحث في مسائل الفروق: كثرة المسائل المتشابهة المتحدة في

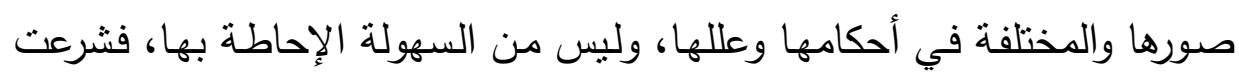

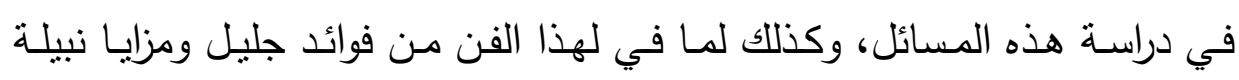
سأذكرها في هذا البحث -إن شاء اله تعالى -. 


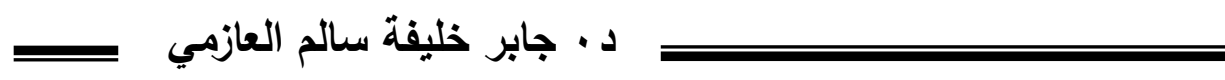
خطة البحث

فقد رسمت لهذا البحث خطة ينتظم عقدها في الآتي:

مقدمة، وأريعة مباحث، وخاتمة.

المبحث الأول: حقيقة الفروق الفقهية.

المبحث الثاني: أهمية علم الفروق الفقهية.

المبحث الثالث: نثأة علم الفروق والمؤلفات فيه.

المبحث الرابع: الفروق الفقهية في باب الصلح

الخاتمة: أهم النتائج -المصادر والمراجع. 


\section{=}

\section{المبحث الأول}

\section{حقيقة الفروق الفقهية}

كلمة الفروق الفقهية مؤلفة من كلمتين: " الفروق "، " الفقهية"، فلا بد من فن فئه

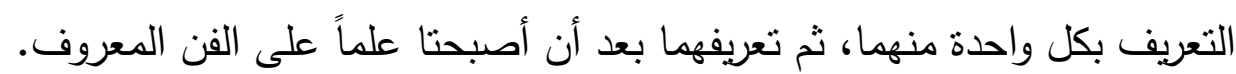

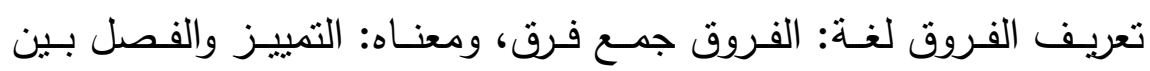

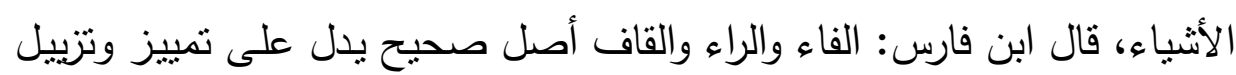

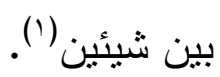

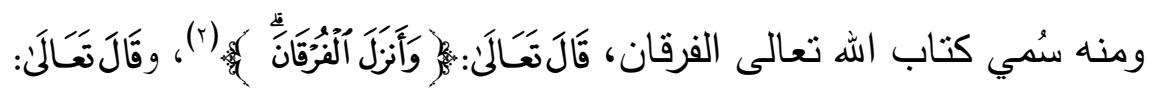

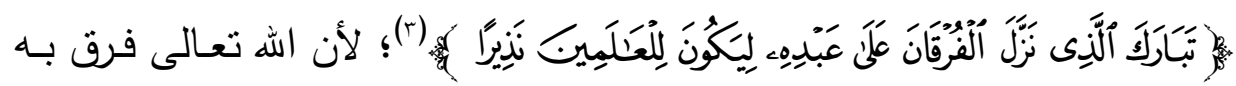
بين الحق والباطل والهدى والضلال.

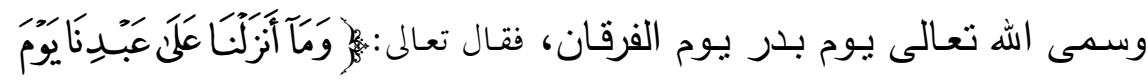

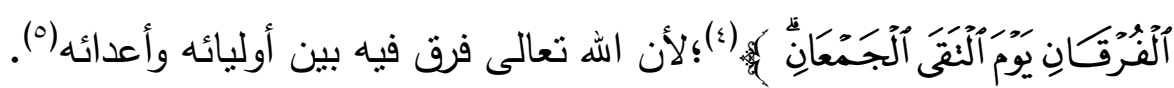

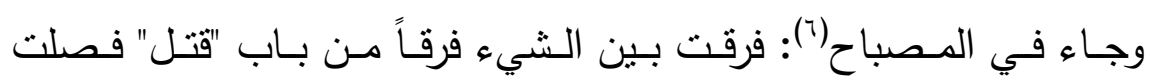

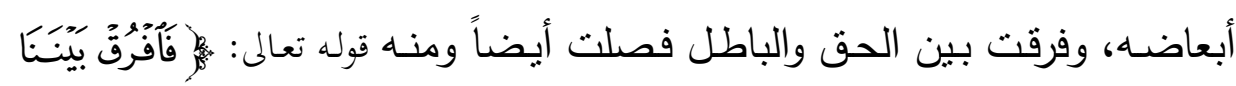

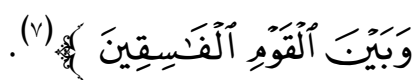

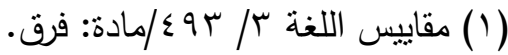

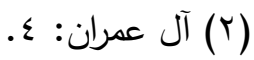

$$
\begin{aligned}
& \text { (ب) الفرقان: } 1 \text { (ال) }
\end{aligned}
$$

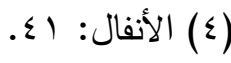

$$
\begin{aligned}
& \text { (0) الروح لابن القيم // / • بـr. }
\end{aligned}
$$

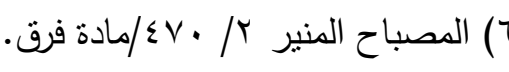

$$
\begin{aligned}
& \text { (V) }
\end{aligned}
$$




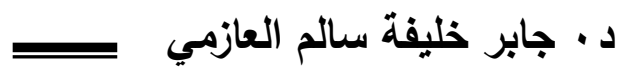

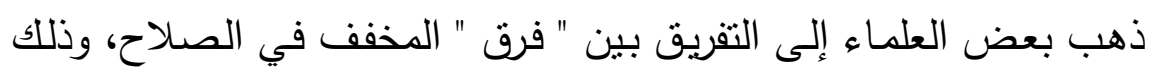

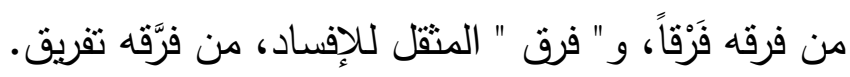

وفرق البعض بين " فَرَق " المخفف، و" فرَّق " المثقل، فجعل المخفف في

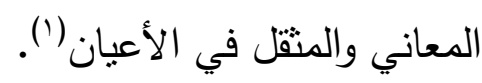

والصحيح أن لا فرق بينهما، فهما بمعنى واحد إلا أن التثقيل مبالغة فإن

كثرة المبنى عند العرب تدل على كثرة المعنى.

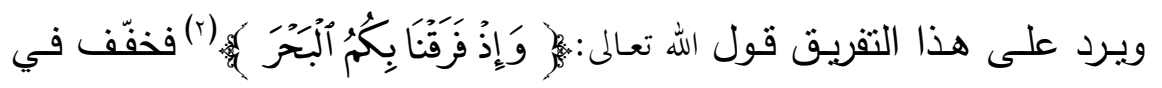

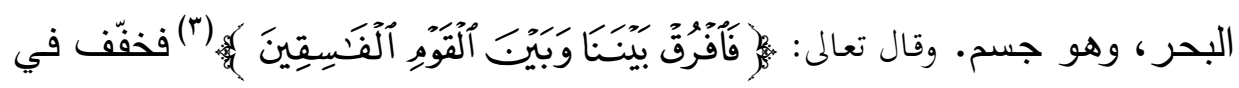

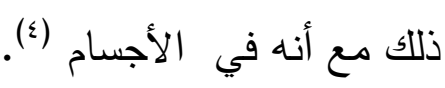

وإن كان لا فرق بينهما -على الصحيح- إلا أن الفقهاء يقولون: ما الفارق

بين المسألتين، ولا يقولون: ما المفرق بينهما بالتشديد (ه).

- تعريف الفروق اصطلاحاً:عرف الأصوليون الفرق بتعريفات كثيرة متباينة

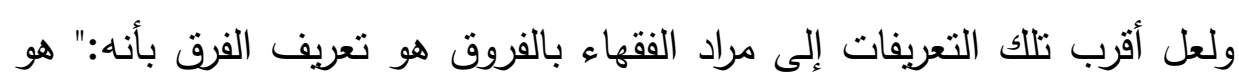

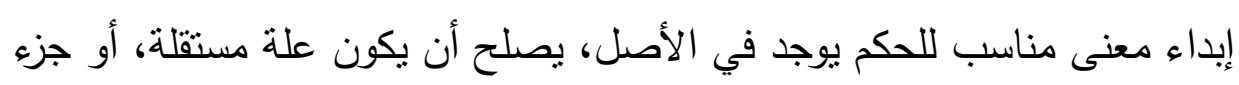

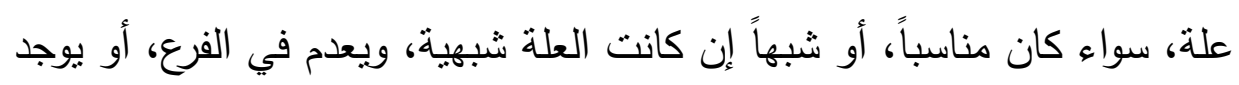

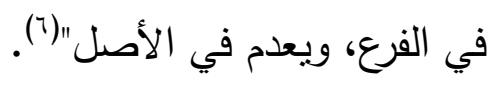

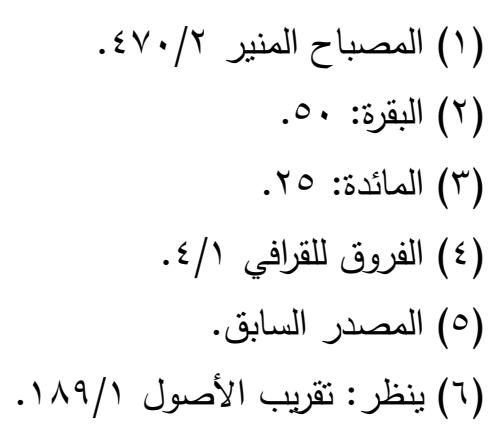


- تعريف الفقه لغة: الفقه لغة: إدراك الثيء، والعلم به، يقال: فَقِهْتُ

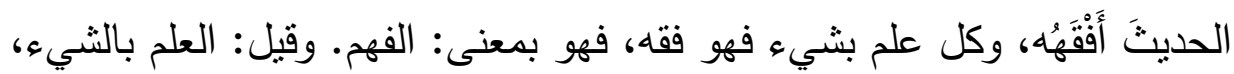

$$
\text { والفهم له (1). }
$$

- تعريف الفقه اصطلاحاً:عرّف الفقه في الاصطلاح بعبارات منتوعة من

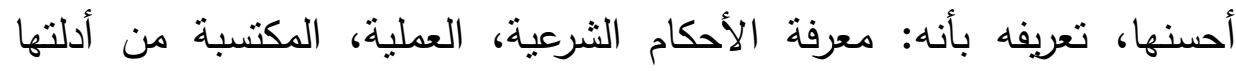

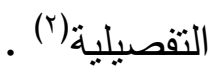

- تعريف علم الفروق الفقهية:عرف علم الفروق الفقيهة بتعريفات منقاربة ومتباينة ومن أنثهرها(†): أنه الفن "الذي يذكر فيه الفرق بين النظائر الفتحدة

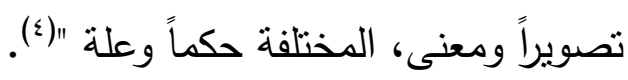
لكن هذا التعريف اعترض عليه من وجوه منها: أحدها- أنه تعريف لا يمنع دخول الفروق بين المسائل المتثابهة في علوم وجره مانيا: أخرى : كالنحو ، واللغة، وغيرهما (ه).

$$
\text { الثاني - أنه وصف لهذا العلم وليس تعريفاً (1). }
$$

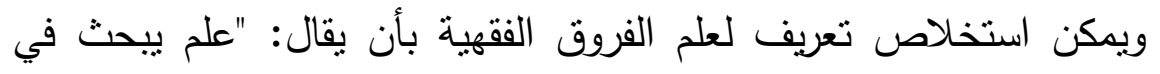

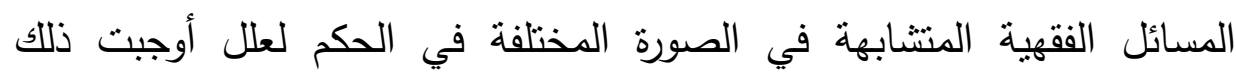

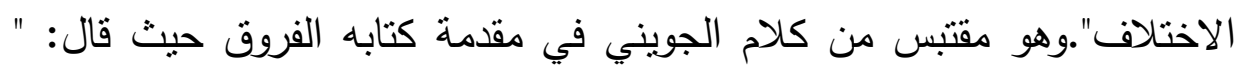

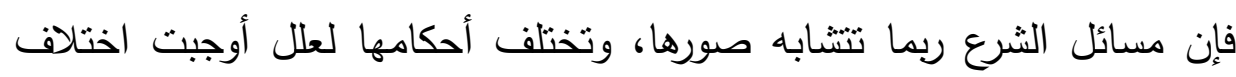

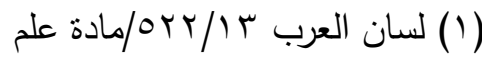

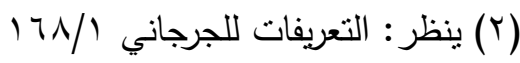

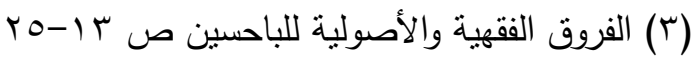

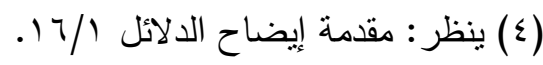

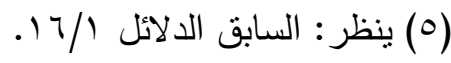

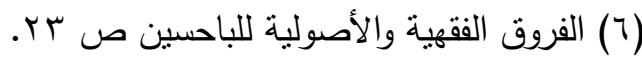

$$
\begin{aligned}
& \text {-r人.- }
\end{aligned}
$$


د · جابر خليفة سالم العازمي

المبحث الثاني

\section{أهمية علم الفروق الفقهية}

إن لعلم الفروق الفقهية أهمية كبيرة وفوائد جليلة في دراسة الفقه الإسلامي؛

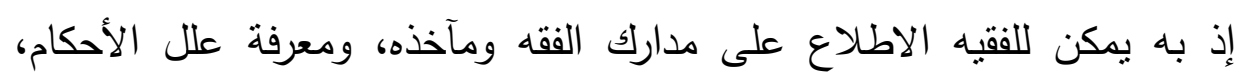

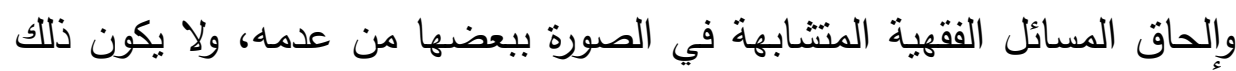

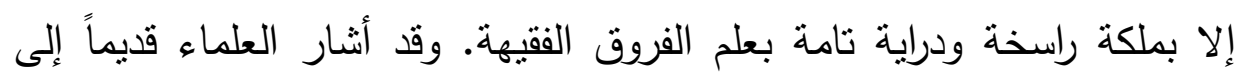

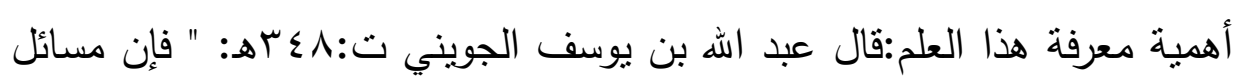

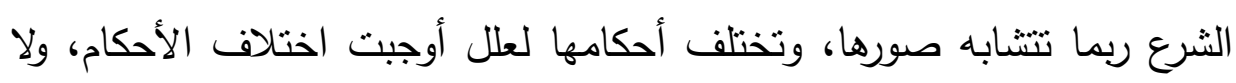

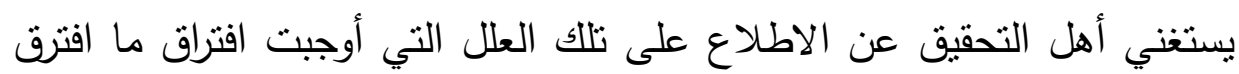
منها، واجتماع ما اجتمع منها ".

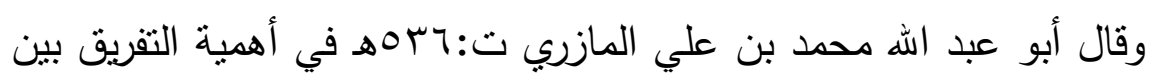

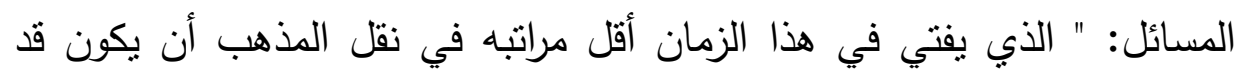

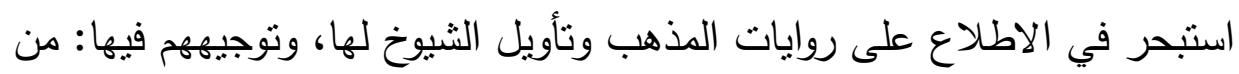
اختلاف ظواهر واختلاف مذاهب، وتتبيههم مسائل بمسائل قد يسبق إلى النفس تباعدها، وتفريقهم بين مسائل ومسائل قد يقع في النفس تقاربها وتنثابهـا

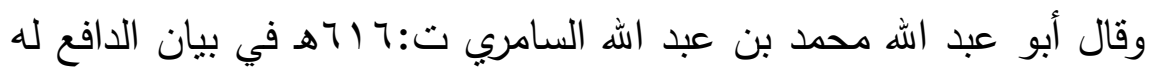

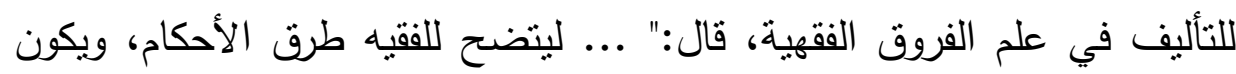

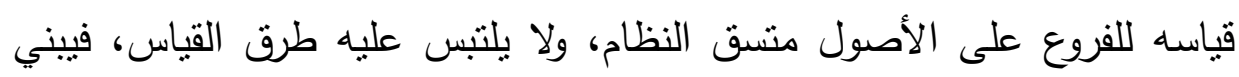

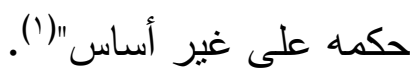

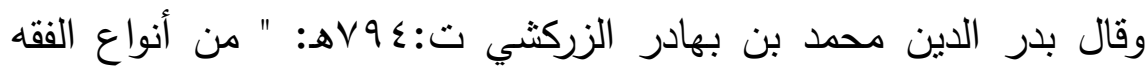

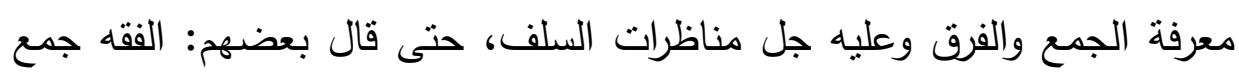




\section{الفروق الفقهية}

وقد حذر أبو القاسم البرزلي ت: اءـهـ ممن يدعي الاجتهاد أو يعمد إلى الى

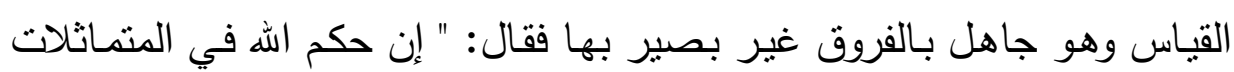

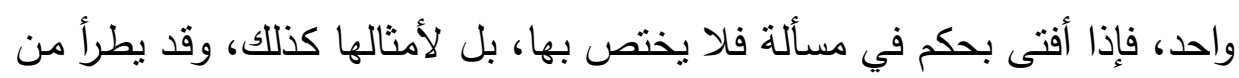

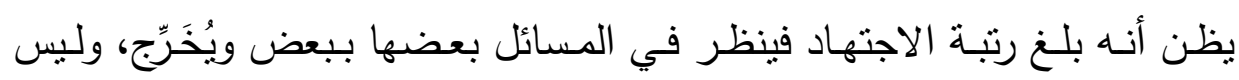

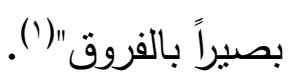

مما سبق وغيره تتضح أهمية علم الفروق ومكانته في الدراسات الشرعية،

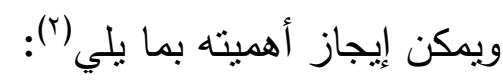

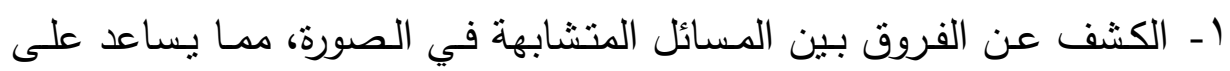

صحة القياس عند صحة الفرق، أو ضعفه في منعه.

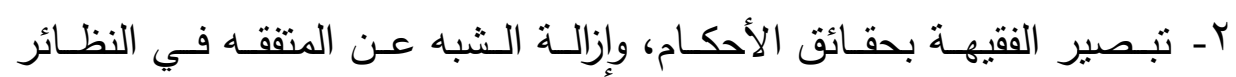

$$
\text { المنتابهة. }
$$

r- دراسة الفروق الفقيـة تكسب الفقيه ملكة وذوقاً فقهيّاً يمكن معه الجمع بين المؤتلف في الحكم، والتفريق بين المختلف، والتمييز بين المسائل المتشابهة،

$$
\text { وإدراك ما بينها من وجوه الاتفاق والافتنراق. }
$$

ـ ـ الرد على من يتهم الفقه الإسلامي بالتتاقض بشبهة أنه يُعطي الأمور المؤتلفة أحكاماً متباينة ويجمع المسائل المتقرقة في حكم واحد.

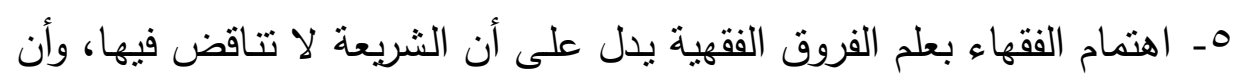

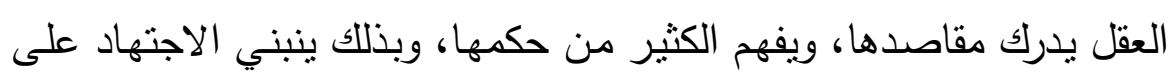
مراعاة المصالح، ويتوخى جلبها، ويعتمد على درء المفاسد وتجنبها.

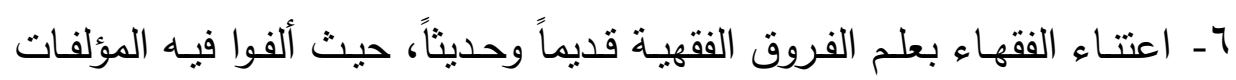
المستقلة، وضَمَنتوه كتب الفقه. وهذا دليل على أهميته.

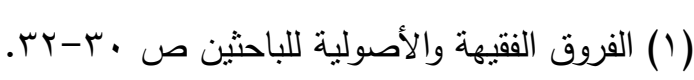

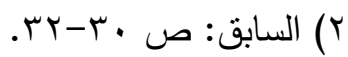

$$
\begin{aligned}
& \text {-rNT- }
\end{aligned}
$$


د · جـابر خليفة سالم العازمي

\section{المبحث الثالث}

\section{نشأة علم الفروق والمؤلقات فيه}

نشأ علم الفروق الفقهية مع نشأة علم الفقه، كما هو الثأن في كل علم، وقد ورد في نصوص الكتاب والسنة ما يشير إلى الفرق بين بعض الفروع المتشابهة،

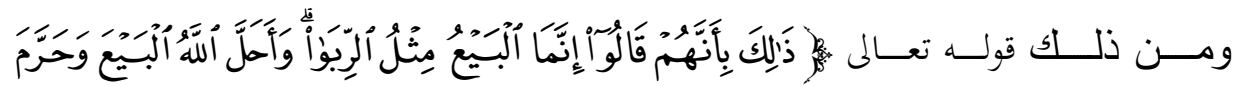

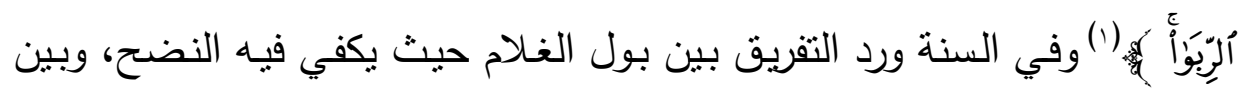
بول الجارية الذي يجب فيه الغسل مع أنّ كلاّ منهما بول طفل. وقد أدرك السلف ذلك منذ صدر الإسـلام فمما جاء في رسالة عمر بن الخطاب إلى أبي موسى الأشـعري - رضـي الله عنهمـا قولـه: " اعرف الأمثنال والأشباه، ثم قس الأمسور عندك، فاعمد إلى أحبها إلى الله وأثبهـها بالحق فيما ترى "(r). قال الإمام السيوطي تعليقاً على هذه النصيحة: " صريحة في الأمر بتتبع النظائر وحفظها ليقاس عليها ما ليس بمنقول، وأن فيها إثنارة إلى أن من النظائر مـا يخالف نظائره في الحكم لمدرك خاص بـه، وهو الفن المسمى بالفروق الذي

يذكر فيه الفرق بين النظائر المتحدة تصويراً أو معنى المختلفة حكماً وعلة"(؟). وقد اعتى الفقهاء بالفوارق المؤثزة بين الفروع المتشابهة، في فتاويهم ومؤلفاتهم، وزاد من عنايتهم به أن أفردوه بالتأليف وخصصوه بالتصنيف.فقد بدأ التأليف فيه في نهاية القرن الثالث الهجري وأوائل القرن الرابع حيث ألف الإمام

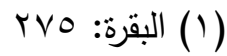

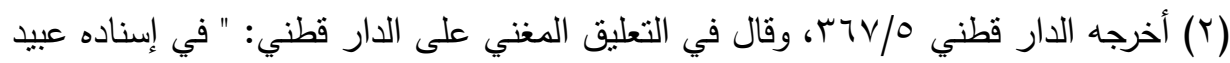

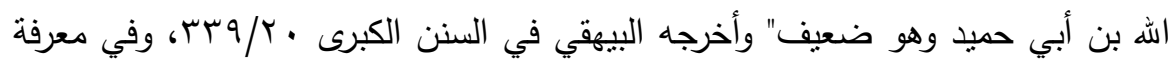

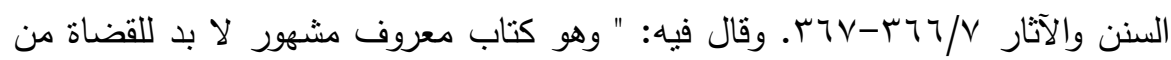




\section{الفروق الفقهية}

ابن سريج ت:7 · به كتابه الموسوم بـ" الفروق" ثم نشطت حركة الثأليف في هذا

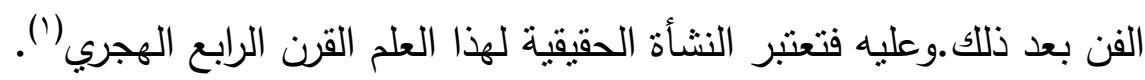
وقد توجه الباحثون في هذا العصر إلى علم الفروق الفقهية، فبدأوا يستخرجون الفروق الفقهية بين الفروع من أبواب الفقه المختلفة ويصنفونها بمصنفات مستقلة بعد دراستها دراسة مقارنة، ويبينون وجه الثباه بينها. المؤلفات في الفروق الفقهية

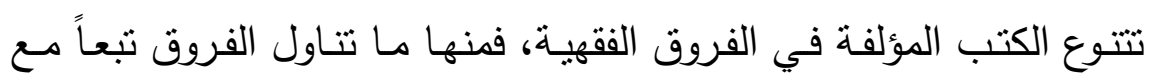

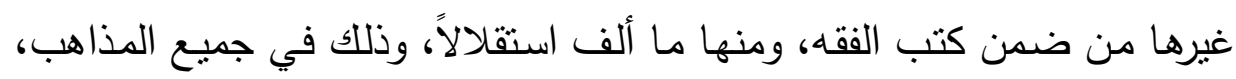
ومن الكتب المؤلفة في الفروق الفقهية:

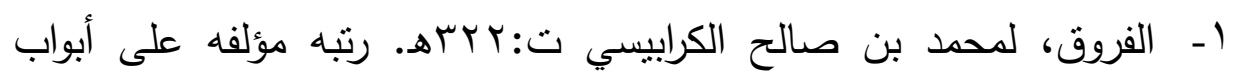

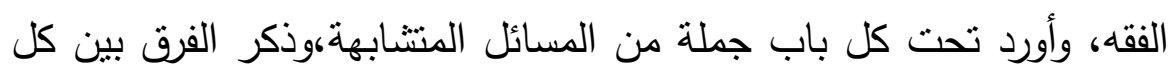
مسألنين وقد حقق الكتاب في رسالة دكتوراه بجامعة أم القرى.

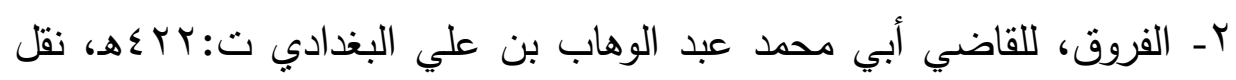
عنه المواق في شرحه على مختصر خليل.

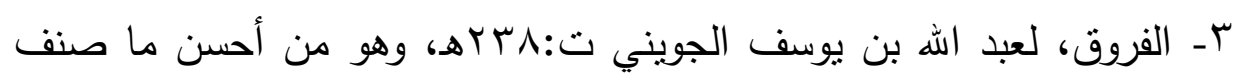

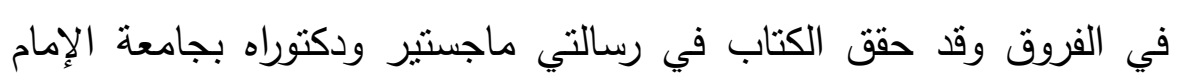

$$
\text { كحمد بن سعود الإسلامية. }
$$

ــ الفروق، لمسلم بن علي بن عبد الله الدمثقي توفي في القرن الخامس الهجري

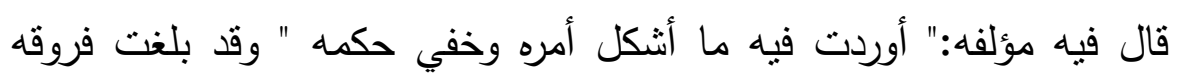

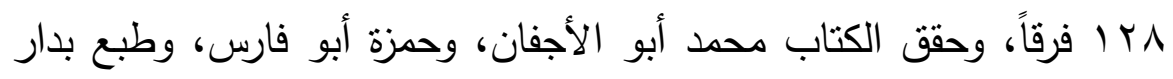

$$
\text { الغرب الإسلامي. }
$$

(1) مقدمة إيضاح الدلائل ro/ r. 


\section{د · جابر خليفة سالم العازمي}

هـ الفروق، لأسعد بن محمد بن الحسين النيسابوري الكرابيسي ت: • VOه، رتبه مؤلفه على أبواب الفقه، وقد احتوى على VV9 فرقاً، طبع بتحقيق الدكتور محمد طموم، وطبعته وزارة الثؤون الإسلامية بالكويت في جزعين. 7- الفروق، لمحمد بن عبد الله بن الحسين السامري ت:ד الآهـ، حقق جزء منه في رسالة ماجستير ، بجامعة الإمام محمد بن سعود الإسلامية. V- تلقيح العقول في فروق النقول، لأحمد بن عبيد الله المحبوبي ت: . بآهـ، حقق في رسالة ماجستير بجامعة الأزهر ('). ^- أنوار البروق في أنواء الفروق، لأبي العباس أحمد بن إدربس القرافي

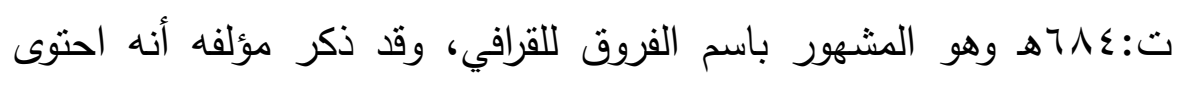
على ^§ه قاعدة، وقد أوضح كل قاعدة بما يناسبها من الفروع، وبين فيه مؤلفه الفروق بين كثير من المسائل الفرعية(r). 9- إيضاح الدلائل في الفرق بين المسائل، لعبد الرحيم بن عبد الله محمد لهن الزريراني ت: إه، وقد رتبه مؤلفه على أبواب الفقه، وهو تهذيب لفروق السامري، وقد أضاف إليه مؤلفه فصولاً أخرى، والكتاب حقق في رسالة دكتوراه بجامعة أم القرى، ونشرته الجامعة فيجزينين(r). • 1 ـ مطالع الدقائق في تحربر الجوامع والفوارق، لعبد الرحيم بن الحسن ابن علي الإسنوي ت:VVY هـ، وهو مرتب على أبواب الفقه، حقق بجامعة الأزهر،

$$
\text { ويحتوي على ع وب فرقاً. }
$$

1 ا ـ الاستغناء في الفرق والاستثتاء، لمحمد بن أبي بكر بن سليمان البكري توفي في القرن التاسع جمع في كتابه بين الفروق الفقهية والقواعد الفقهية، وقد

$$
\begin{aligned}
& \text { (1) (1) إيضاح الدلائل /9/1) }
\end{aligned}
$$

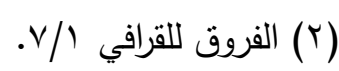

$$
\begin{aligned}
& \text { (r) ينظر : مقدمة إيضاح الدلائل ص } 1 \text { (Y) }
\end{aligned}
$$




\section{الفروق الفقهية}

رتبه مؤلفه على أبواب الفقه، حقق جزء منه في رسالة دكتوراه بجامعة الإمام

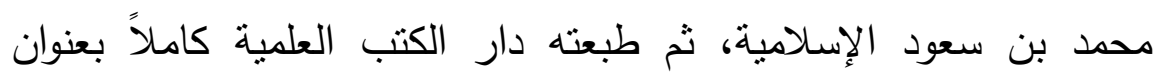
"الاعتتاء في الفرق والاستنثاء".

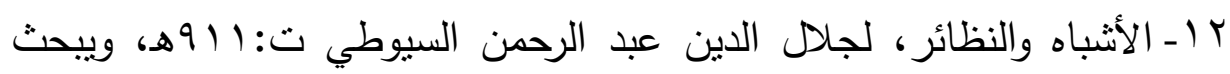
الكتاب في القواعد الفقهية فيما يختص القسم السادس منه بالفروق الفيد الفقهية،

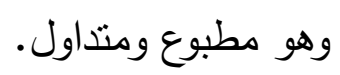

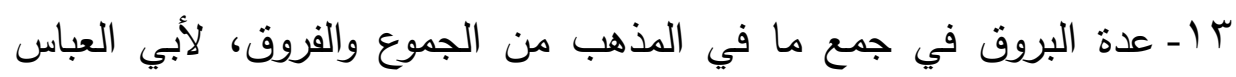

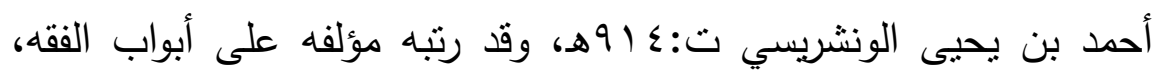

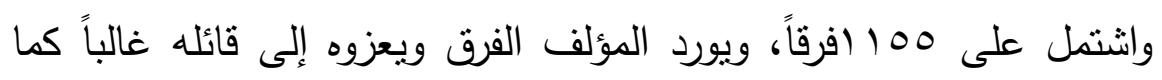

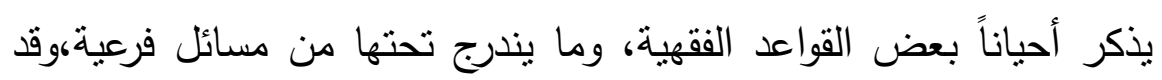

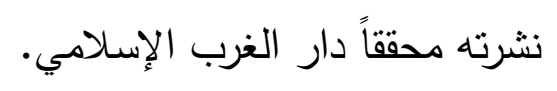

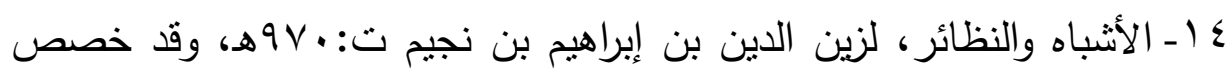

$$
\text { المؤلف جزءاً منه في الفروق الفقهية. وهو مطبوع. }
$$

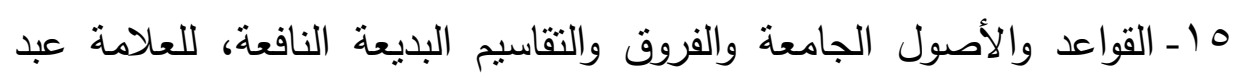

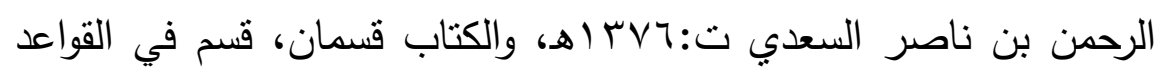
والأصول،والثاني في الفروق الفقهية بين المسائل المنثابهة والأحكام المتقاربة والتقاسيم المهمة، وهو مطبوع ومتداول. 


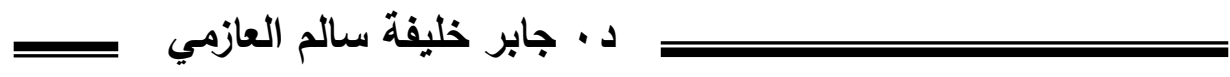

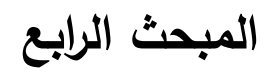

\section{الفروق الفقيهة في باب الصلح}

\section{- المسألة الأولى:}

إذا أقرَّ له بألف حالة، فصالحه هنها على خمسمائة حالَّة، جاز • ولو أقرَّ له

بألف مؤجَّلة، فصالحه منها على خمسمائة حالَّة، لم يجز ('). صورة المسألة:

رجل في ذمته لآخر مائة درهم مؤجلة إلى سنة، وفي أثناء السنة جاء الدائن

للمدين، وقال: أعطني منها خمسين وأبرئك من الباقي (ب).

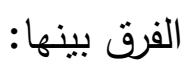

أن الألف الحالَّة يستحق المطالبة بجميعها فإذا صالحه على خمسمائة منها حالَّة فقد أبرأه من خمسمائة، وطالبه بالباقي والبعض المأخوذ غير مستفاد بعقد

$$
\text { الصُّلح وإنما بسبب العقد السابق ("). }
$$

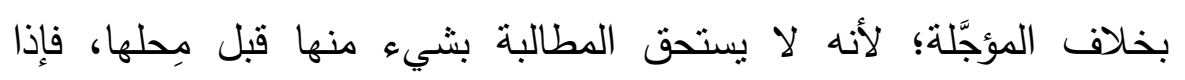

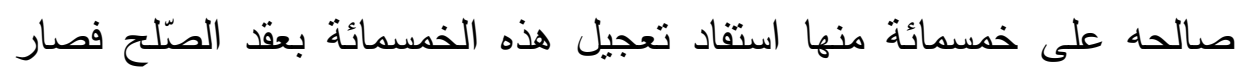
كأنه باع ألفا مؤجَّلة بخمسمائة حالة وذلك لا يجوز لأنه ربا. 


\section{خلاف الفروق الفقهية

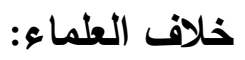

القول الأول: ذهب جمهور الفقهاء من الحنفية(') والمالكية(') والثافعية(') والحنابلة(') إلى أنه إذا كان لِرجل على آخر دين مؤجل، فقال الددين لغريمه:

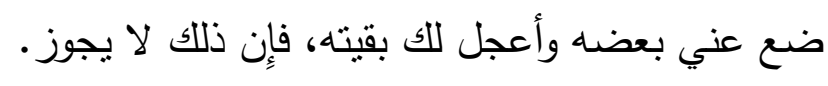

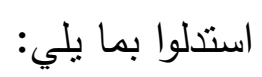

1- أن هذا ربا ومعلوم أن ربا الجاهلية إنما كان قرضا مؤجلا بزيادة مشروطة، فكانتِ الزيادة بدلاً مِن الأجل.

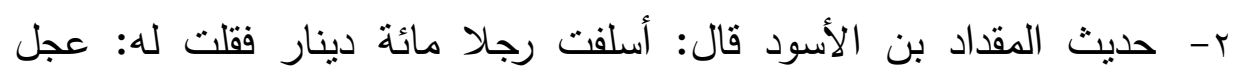
تسعين وأحط عشرة دنانير • فقال: نعم. فذكرت ذللك للنبي صلى الله عليه

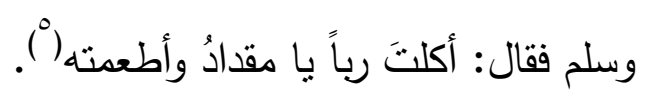

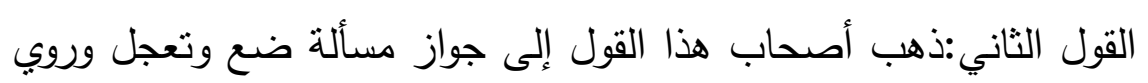

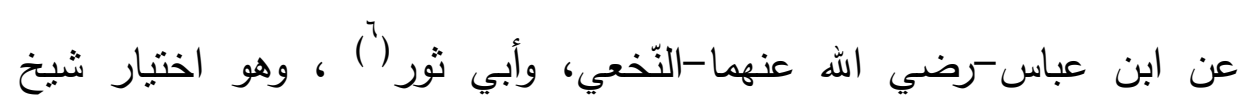

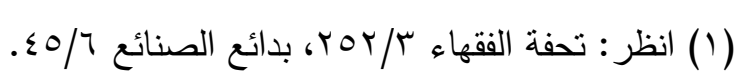

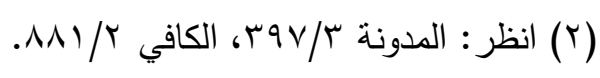

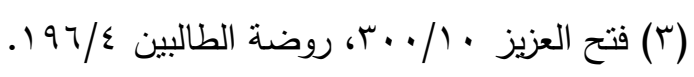

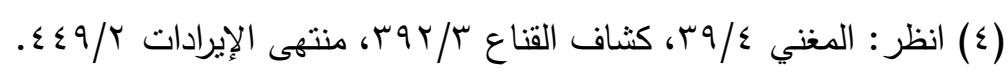

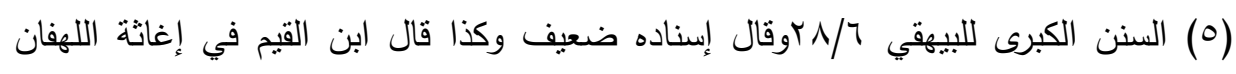

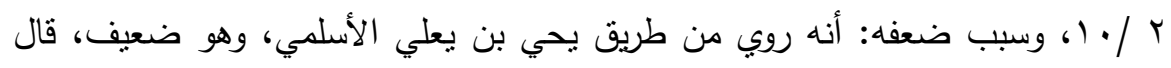

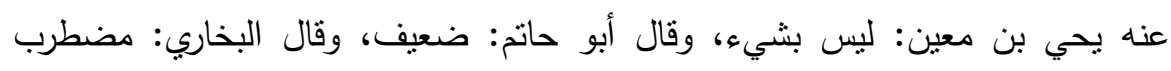

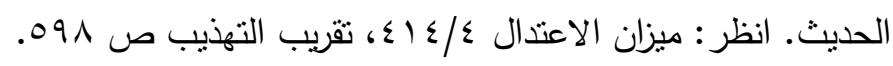

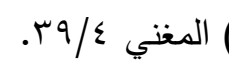




\section{د · · بابر خليفة سالم العازمي}

الإسلام بن تيمية(') ، وتلميذه بن القيم(') ، واختاره أيضا وابن سعدي، وتلميذه ابن

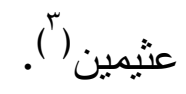

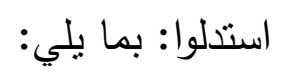

ا - حديث ابن عباس رضي الله تعالى عنهما قال: لما أراد رسول الله صلى الله عليه وسلم أن يخرج بني النضير قالوا: يا رسول الله، إنك أمرت بإخراجنا ولنا

$$
\text { على الناس ديون لم تحل. قال: "ضعوا وتعجلوا"("). }
$$

r- مصلحة للطرفين، أما الطالب فمصلحته التعجيل، وأما المطلوب فمصلحته الإسقاط، ومن المعلوم أن الشريعة لا تأني بمنع عقد فيه مصلحة للطرفين،

$$
\text { وليس فيه غرر ولا جهالة. }
$$

r- أن المدين لم يطرأ على باله حين استدان أنه سوف يرده أنقص معجلاً،

$$
\text { فمحظور الربا بعيد جداً (") }
$$

ع- أن المسألة نتنمل على إسقاط وتعجيل، والإسقاط مفرداً يصح، والتعجيل مفرداً بصح؛ فإذا اجتمعا صح العقد؛ لأنه مكون من أمرين جائزين. القول الراجح: هو ما ذهب إليه أصحاب القول الثاني لقوة أدلتهم.

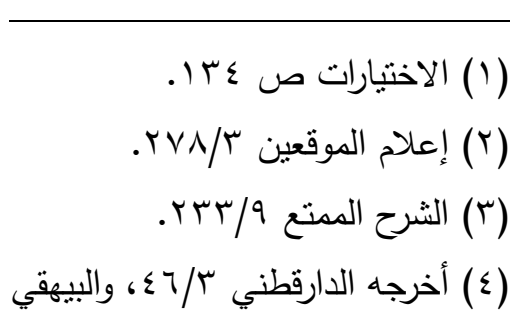

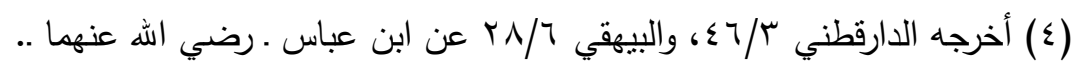

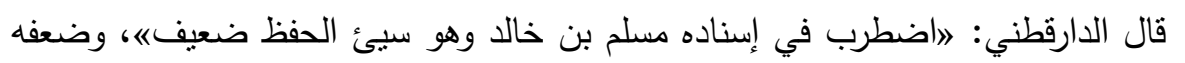
ابن القطان، انظر: "بيان الوهم والإيهامه رقم ابـى .قال عنه ابن حجر في " التقريب ": صدوق كثير الأوهام قال ابن معين: ليس به بأسوقال مرة: نقة.

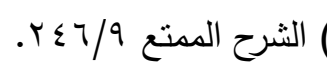




\section{=}

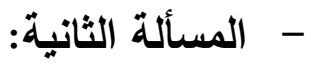

لا يصح الصلح عن الثفعة بمال وتسقط الثفعة، ولو صالح عن القصاص

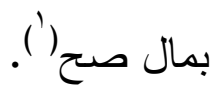

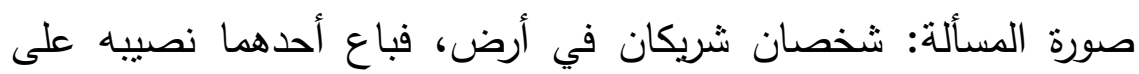

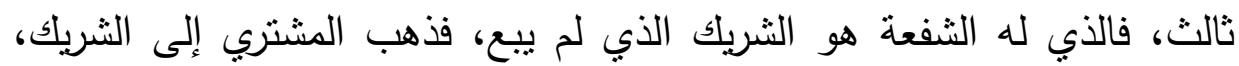

وقال: أنت للك حق الثفعة، ولكن أنا سأعطيك عشرة آلاف ربال وأسقط حقلك (').

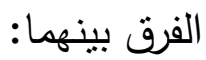

أن الثفعة ثبتت في الأصل لدفع الضرر، فإذا سقطت أو أسقطت إلى غير

$$
\text { مال لأنها لم توضع لاستفادته آ"ا. }
$$

بخلاف القصاص فإنه بمعنى العوض فإذا أسقط رجع إلى المال، فصح

$$
\text { خلاف العلم كخيار العيب(أ). }
$$

اختلف الفقهاء في جواز التتازل عن الثفعة مقابل تعويض يأخذه الثفيع.

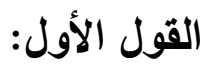

ذهب جمهور الفقهاء من الحنفية(')، والثافعية(7)، والحنابلة(')، لا يصح

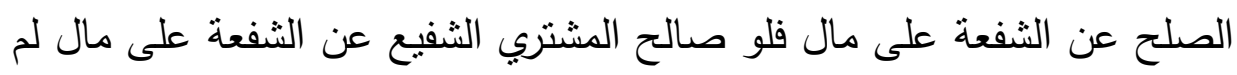
يجز الصلح ولم يثبت العوض ويبطل حق الثفعة.

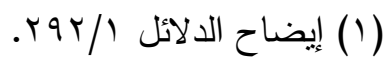

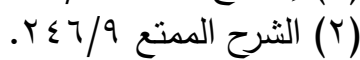

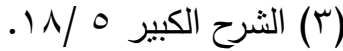

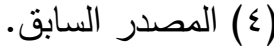

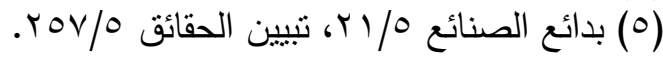

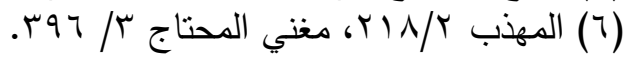

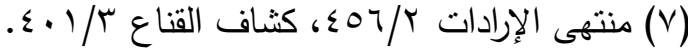

$$
\begin{aligned}
& -r q .-
\end{aligned}
$$


د · جابر خليفة سالم العازمي

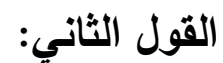

ذهب ماللك إلى جواز الصلح عن الثفعة بعوض واختاره ابن عثيمين ('). دليله: لأنه عوض عن إزالة الملك فجاز أخذ العوض عنه. القول الراجح -واله أعلم-هو ما ذهب إلبه القول الثاني لما يلي: أن حق إنه الثفعة يتعلق بالمال، فهو حق آدمي فالمشتري صالح الثفيع عن حق لله فهو حق محض للآدمي، فإذا أسقط الآدمي حقه بعوض فلا بأس بذلك.

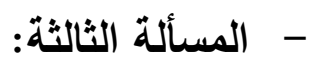

يصح الصلح عن دم العدد بأكثر من الدية وبأقل منها، ولا يصح الصلح عن قتل الخطأ بأكثر من الدية من جنس الدية('). الفرق بينهما:

أن الواجب بقتل العمد لا يخلو إما أن يكون القود فقط، أو أحد شيئين القود أو الدية والخيار في ذلك للورثة فعلى كل حال للورثة القود ولو بذل القاتل أضعاف الدية على أن لا يقتصوا منه لم يلزمهم ذلك إلا باختيارهم.

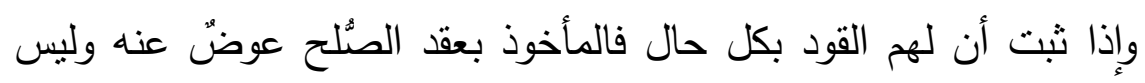
من جنسه فجاز من غير تقدير كسائر المعاوضات الجائزة('). وليس كذلك قتل الخطأ لأن الواجب به الدية لا غير ، والدية مقدَّرة شرعا، فلا يجوز الصُّلح بأكثر منها من جنسها؛ لأن ذلك ربا فهو كما لو كان له في ذمة لهانه إنسان دينار فصالحه عنه بدينار ونصف فإنه لا يجوز كذلك هاهنا. صورة المسألة: أن يصالح صاحب الحق عن الحق بأكثر من المبلغ المستحق من جنسه، كأن بصالح عن مائة من الإبل بمائة وعشرين من الإبل.

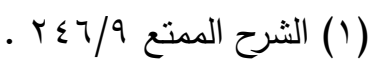

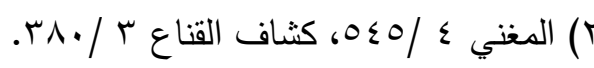

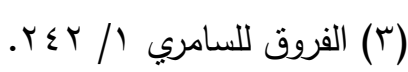


القول الأول: ذهب جمهور الفقهاء من الحنفية(')، والمالكية(')

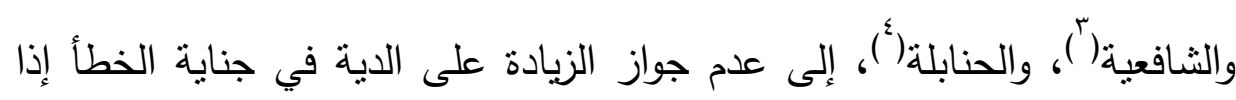
كان المصالح عليه من جنس الدية.

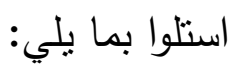

الدليل الأول: أن الدية ثبتت في الذمة مقدرةفلم يجز أن يصالح عنها بأكثر

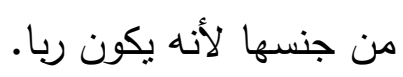
الدليل الثاني: أنه إذا أخذ أكثر منها فقد أخذ حقه وزيادة لا مقابل لها،

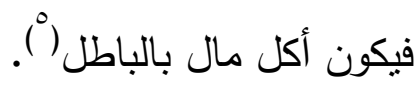

القول الثاني: جواز الصلح على أكثر من الدية وهو اختيار ابن تيمية(").

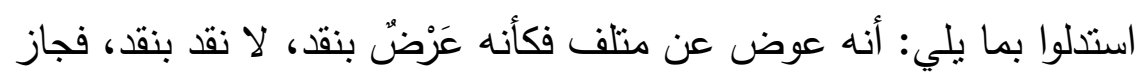

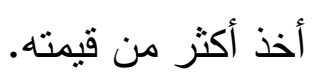
القول الراجح:هو القول الأول؛ لقوة أدلته ووجاهنها وظهورها، وضعف أدلة

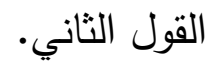

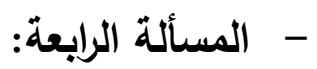

إذا أتلف عليه منقوم، لم يجز أن يصالح عنه بأكثر من قيمته من جنسها،

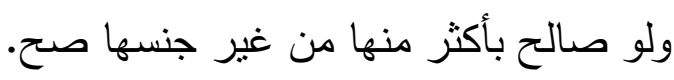

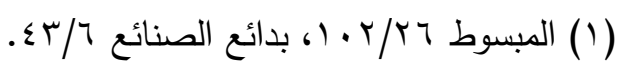

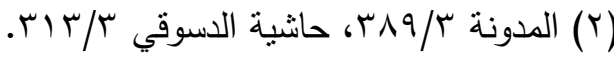

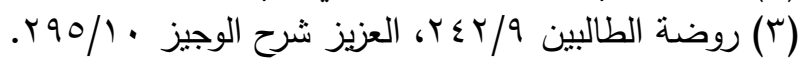

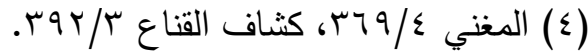

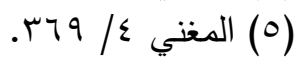

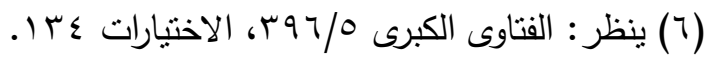




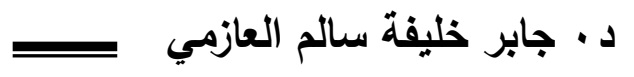

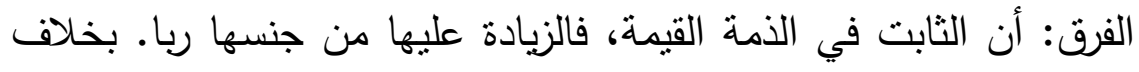

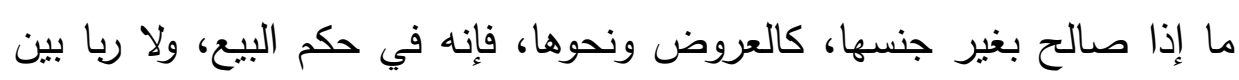
النقدين والعروض، فظهر الفرق. والخلاف فيها كالخلاف في المسألة التي قبلها.

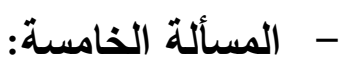

قد تقرر: أنه إذا صالح عن مثلف متقوم بأكثر من قيمته من جنسها لم يجز • ولو صالح عن متلف منلي بأكثر من قيمته من جنسها جاز .

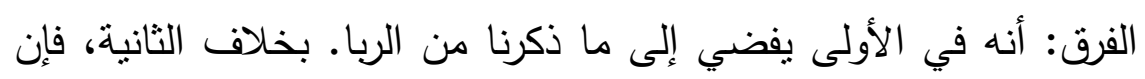

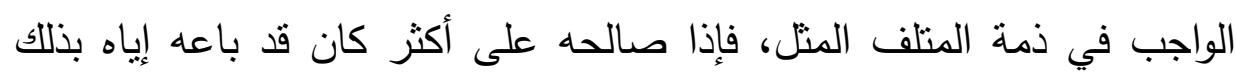
فيصح، كما لو كان عينا حاضرة. والله أعلم، وصلى الله على نبينا محمد، وعلى أله، وصحبه أجمعين... 


\section{الفروق الفقهية}

\section{الخاتمة}

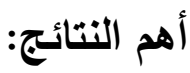

- إن علم الفروق الفقهية نثأ مع نثأة علم الفقه نفسه؛ لأنه جزء منه، ثم بدأ الاهتمام به شيئا فثيئًا.

- اعتتاء الفقهاء بعلم الفروق الفقهية قديماً وحديثاً، حيث ألفوا فيه المؤلفات المستقلة.

- إن علم الفروق الفقهية يبحث في أوجه الافتراق من المسائل الفقهية المتفق

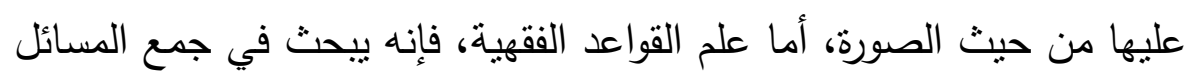
المتشابهة من أبواب مختلفة تحت حكم واحد.

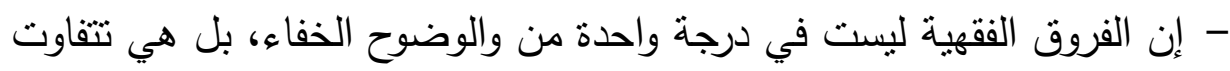
في ذللك، فمنها ما هو واضح ومنها ما هو غامض ليحت فئاج إلى توضيح.

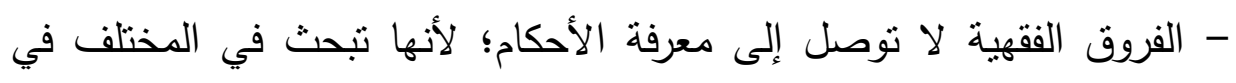

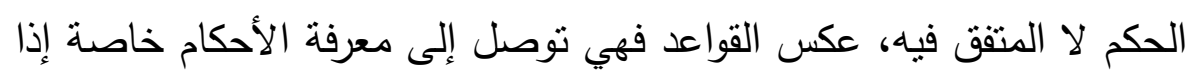
كان حكمها منصوصًا عليه. - إن الفروق الفقهية لها أهمية بالغة في مجال الدهانها

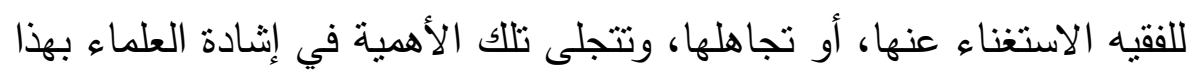
الفن، والفوائد المترنبة على دراسته ومعرفته. - إن هذا العلم بكثفه عن الفروق بين المسائل يحقّق وضوحًا في علل الأحكام،

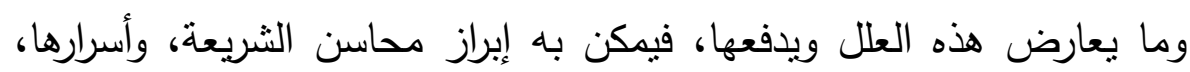
وحكمها، ومقاصدها، ومآخذها. 
د · جابر خليفة سالم العازمي

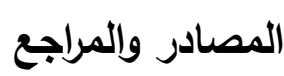

- الاختيارات الفقهية من فتاوى شيخ الإسلام ابن ثيمية، لعلي بن محمد البعلي المتوفى r ب هـ، تحقيق محمد الفقي، الناشر مطبعة السنة المحمدية الطبعة:

$$
.190 .-11799
$$

- الأشباه والنظائر، لعبد الرحمن بن أبي بكر، جلال الدين السيوطي المتوفى:

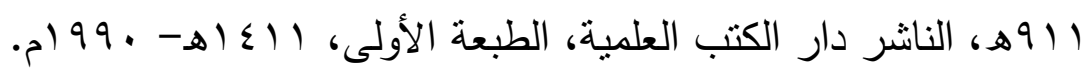
- إعلام الموقعين عن رب العالمين، لمحد بن أبي بكر بن أيوب بن سعد

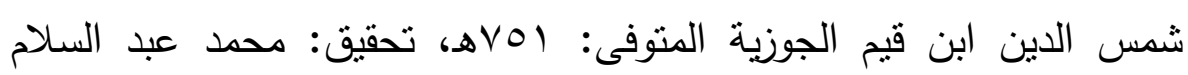

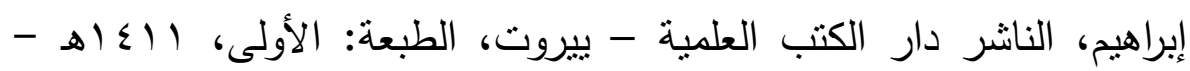

$$
\text { . } 1991
$$

- بدائع الصنائع في ترنيب الثرائع، لعلاء الدين، أبي بكر بن مسعود بن أحمد الكاساني الحنفي، المتوفى: ONVهـ، الناشر دار الكتب العلمية، الطبعة:

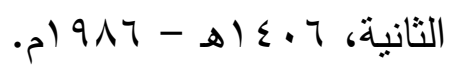

- بدائع الصنائع في ترتيب الشرائع ، علاء الدين، أبي بكر بن مسعود بن أحمد الكاساني الحنفي، المتوفى: ONVهـ، الناشر دار الكتب العلمية، الطبعة:

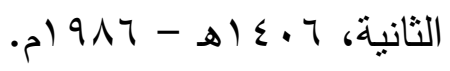

- ثبيين الحقائق شرح كنز الدقائق، لعثمان بن علي بن محجن البارعي، فخر الدين الزيلعي الحنفي، المتوفى: س V هـ الناشر : المطبعة الكبرى الأميرية -

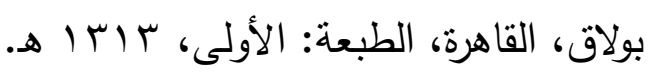

- تحفة الفقهاء، لمحمد بن أحمد بن أبي أحمد، أبي بكر علاء الدين السمرقندي المتوفى: نحو • ؛ هـ، الناشر : دار الكتب العلمية، بيروت-لبنان، الطبعة:

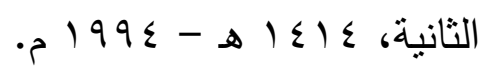

- تقريب الوصول إلي علم الأصول مطبوع مع: الإثارة في أصول الفقه، أبي القاسم، محمد بن أحمد بن محمد بن عبد الله، ابن جزي الكلبي الغرناطي، 


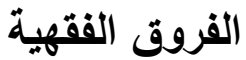

المنوفى: الاكي Vه، تحقيق، محمد حسن محمد حسن إسماعيل، الناشر دار

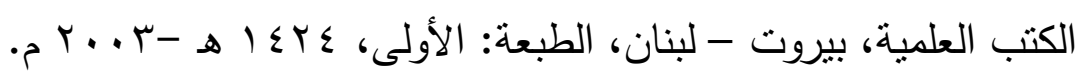

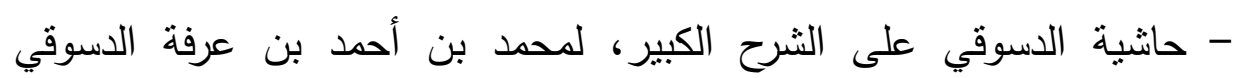

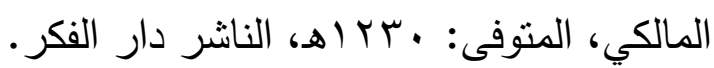

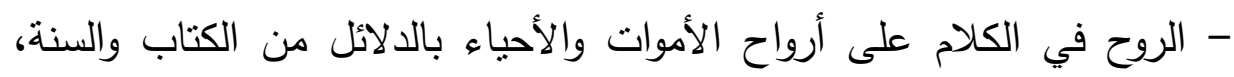

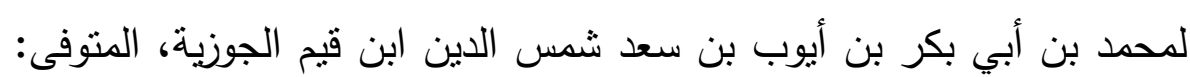

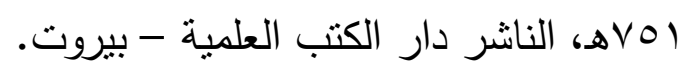

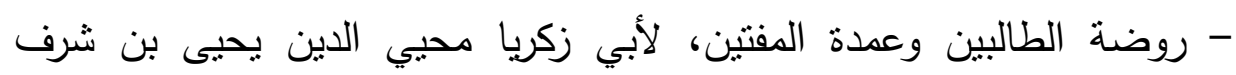

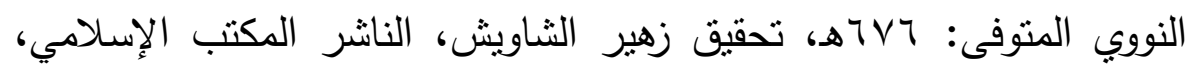

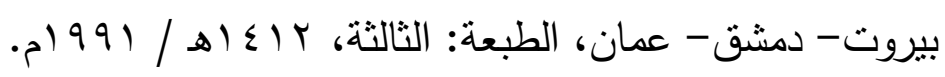

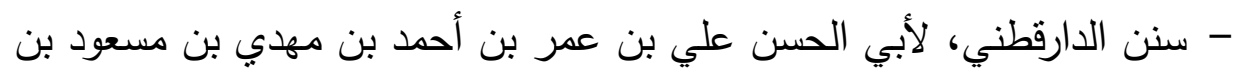

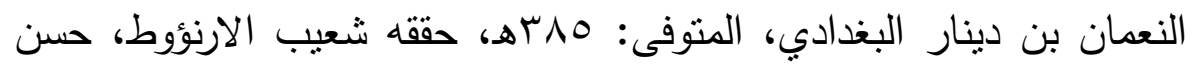

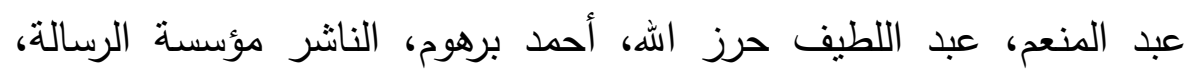

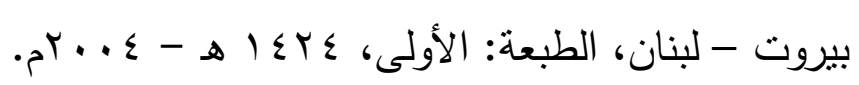

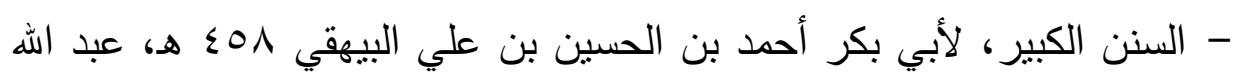
بن عبد الدحسن التركي، الناشر مركز هجر للبحوث والدراسات العربية،

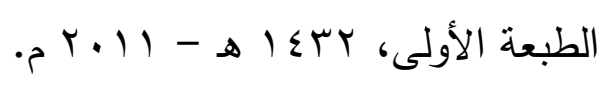

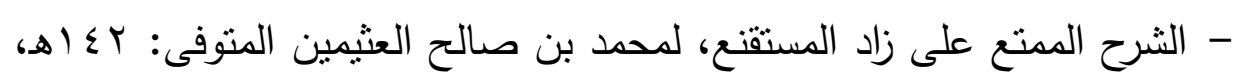

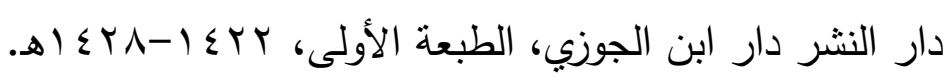

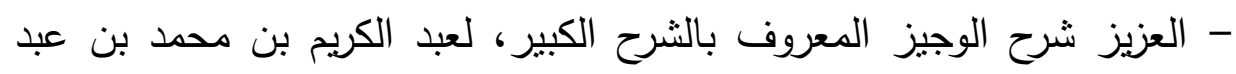

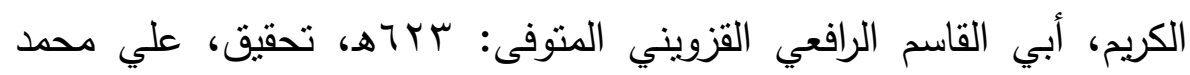
عوض - عادل أحمد عبد الموجود، الناشر دار الكتب العلمبة، بيروت -

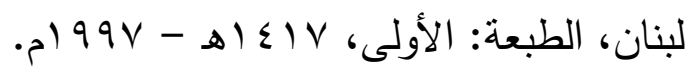




\section{د · · جابر خليفة سالم العازمي}

- فتح العزيز بشرح الوجيز ، الثرح الكبير، لعبد الكريم بن محمد الرافعي القزويني المتوفى: بז7هـ، الناشر: دار الفكر.

- الفروق الفقهية والأصولية، ليعقوب بن عبد الوهاب بن يوسف الباحسين التميمي، الناشر: مكتبة الرشد - الرياض، الطبعة: الأولى، 9 1ـ 1 هـ -

$$
\text { . } 1991
$$

- الفروق على مذهب الإمام أحمد بن حنبل لمعظم الدين أبو عبد الله السامري هبه -77 ا7 هـ، دراسة وتحقيق: محمد بن إبراهيم بن محمد اليحيى، الناشر دار الصميعي للنشر والتوزيع، الرباض - المملكة العربية السعودية، الطبعة:

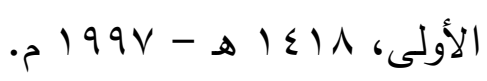

- الفروق، أنوار البروق في أنواء الفروق، لأبي العباس شهاب الدين أحمد بن إدريس بن عبد الرحمن المالكي الثهير بالقرافي، المتوفى: عـآهـ، الناشر:

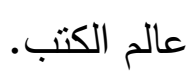

- الكافي في فقه أهل المدينة، أبي عمر يوسف بن عبد الهه بن محمد بن عبد

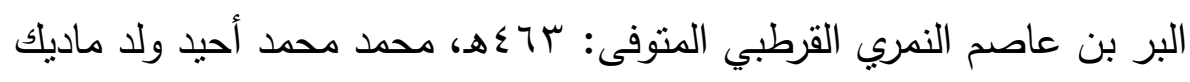
الموريتاني، الناشر: مكتبة الرياض الحديثة، الرياض، المملكة العربية

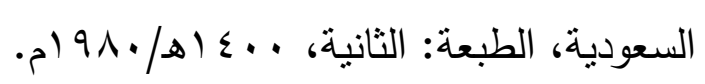

- كتاب التعريفات، لعلي بن محمد بن علي الزين الثريف الجرجاني المتوفى:

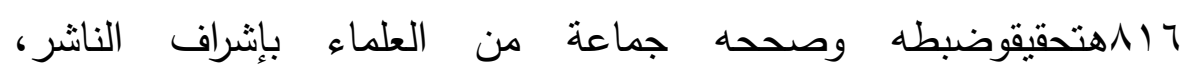

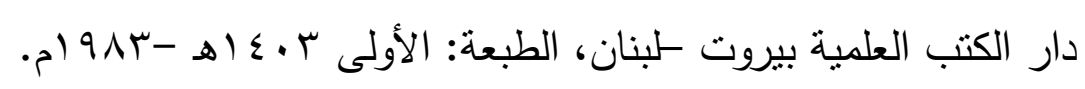
- كثاف القناع عن منن الإقناع لمنصور بن يونس بن صلاح الدين ابن حسن بن إدريس البهوتى المتوفى: 01 ـ اهـ، الناشر : دار الكتب العلمية. - لسان العرب، لمحمد بن مكرم بن على، أبي الفضل، جمال الدين ابن منظور المتوفى ل اله، الناشر دار صادر بيروت، الطبعة الثالثة 


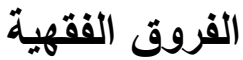

- المبسوط، لمحد بن أحمد بن أبي سهل شمس الأئمة السرخسي، المتوفى:

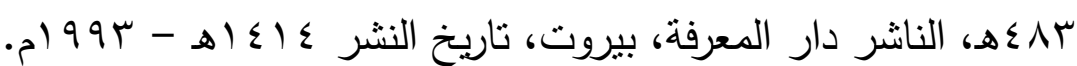

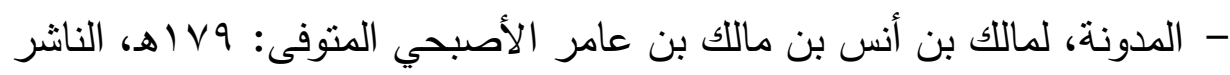

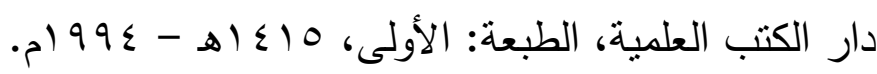

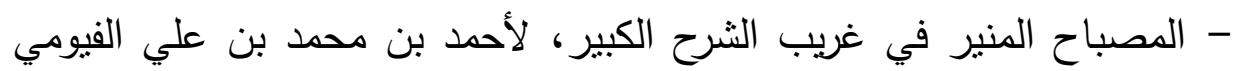
الحموي، المتوفى: نحو • •Vه، الناشر : المكتبة العلمية - بيروت.

- معجم مقاييس اللغة، لأحمد بن فارس بن زكرياء القزويني، المتوفى: 9 بهاهـ،

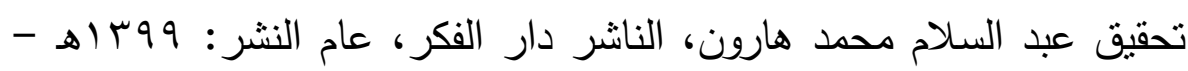

$$
\text { . } 19 \vee 9
$$

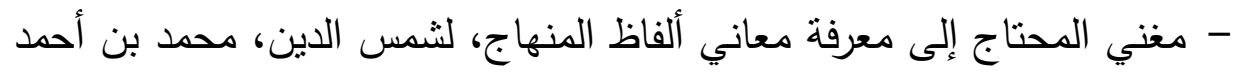
الخطيب الثربيني الثافعي، المنوفى: 9VVهـ الناشر دار الكتب العلمية

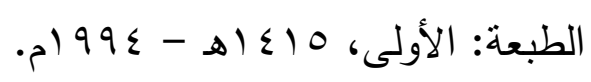

- المغني،لأبي محمد موفق الادين عبد الله بن أحمد بن محمد بن قدامة

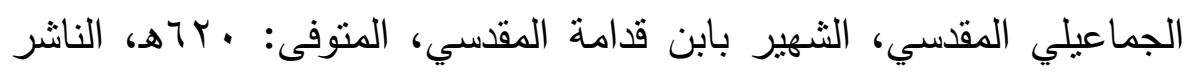

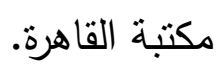

- منتهى الإرادات، لتقي الدين محمد بن أحمد الفتوحي الحنبلي الثهير بابن النجار بوqه، تحقيق، عبد اله بن عبد المحسن التركي، الناشر مؤسسة

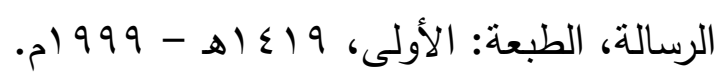

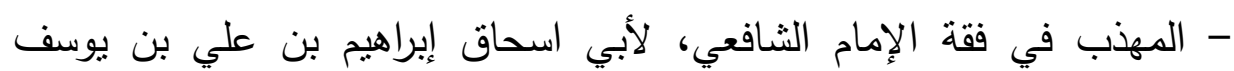
الثيرازي المنوفى: Tحگهـ، الناشر دار الكتب العلمية. 